\title{
PENGARUH KOMUNIKASI KEPALA SEKOLAH TERHADAP KINERJA GURU DAN STAF PEGAWAI PADA SMP SWASTA SULTAN AGUNG PEMATANGSIANTAR
}

\author{
Oleh: \\ L y n i \\ S1 Manajemen \\ Pinondang Nainggolan, Parman Tarigan, Marisi Butarbutar
}

\begin{abstract}
Abstraksi
Adapun rumusan masalah dalam penelitian ini adalah komunikasi yang diberikan oleh Kepala Sekolah pada SMP Swasta Sultan Agung Pematangsiantar terhadap kinerja guru dan staf pegawainya. Tujuan dari penelitian ini untuk mengetahui bagaimana komunikasi yang diterapkan dan seberapa besar pengaruh komunikasi terhadap kinerja guru dan staf pegawai pada SMP Swasta Sultan Agung Pematangsiantar, serta mengetahui hal-hal apa saja yang perlu diperbaiki dan dipertahankan agar mampu menghasilkan kinerja yang baik melalui penerapan komunikasi. Untuk menjawab masalah di atas, penulis melakukan penelitian melalui penelitian kepustakaan dan penelitian lapangan. Metode pengumpulan data yang digunakan adalah metode kuesioner, metode wawancara dan metode dokumentasi. Sedangkan untuk menganalisa data digunakan metode analisa deskriptif kualitatif dan metode analisa deskriptif kuantitatif.

Hasil analisa menunjukkan pengaruh positif antara kedua variable dengan kekuatan hubungan sedang yaitu sebesar 0,5722. Koefisien determinasi sebesar 32,74\% artinya kinerja guru dan staf pegawai dapat dijelaskan oleh komunikasi kepala sekolah dan 67,26 \% dapat dijelaskan oleh faktor lain yang tidak dibahas dalam penelitian ini. Dari hasil penelitian, penulis memperoleh kesimpulan bahwa komunikasi kepala sekolah berpengaruh positif terhadap kinerja guru dan staf pegawai pada SMP Swasta Sultan Agung Pematangsiantar. Hal ini ditunjukkan melalui uji hipotesis $t_{\text {hitung }}>$ dari $t_{\text {tabel }}(4,068>2,033)$. Akan tetapi, kinerja guru dan staf pegawai selain harus dipertahankan, juga harus ditingkatkan. Oleh karena itu perlu adanya peningkatan komunikasi secara terus menerus pada SMP Swasta Sultan Agung Pematangsiantar.
\end{abstract}

Kata kunci: Komunikasi dan Kinerja

\section{Abstraction}

The formulation of the problem in this research is the communication provided by the Principal Private SMP Sultan Agung Pematangsiantar the performance of teachers and staff employees. The purpose of this study to determine how communication is applied and how much influence the communication on the performance of teachers and staff employees at private junior Pematangsiantar Sultan Agung, and to know what are the things that need to be repaired and maintained to be able to produce a good performance through the application of communication. To answer the above problem, the author conducted research through library research and field research. Data collection methods used were questionnaires, interviews and documentation methods. While the data used to analyze the qualitative descriptive analysis method and quantitative descriptive analysis method.

The analysis shows a positive influence between the two variables with the strength of the relationship being that is equal to 0.5722. The coefficient of determination of $32.74 \%$ means that the performance of teachers and staff employees can be explained by the principal communications and $67.26 \%$ can be explained by other factors not addressed in this study. From the research, the authors came to the conclusion that the principal communication has a positive effect on the performance of teachers and staff employees at private junior Pematangsiantar Sultan Agung. This is demonstrated through hypothesis testing t count $>$ t table (4.068> 2.033). However, the performance of teachers and staff employees in addition to be preserved, must also be increased. Hence the need for continuous communication improvement on SMP Private Pematangsiantar Sultan Agung.

Keywords : Communication and Performance

\section{A. PENDAHULUAN}

\section{Latar Belakang Masalah}

SMP Swasta Sultan Agung Pematangsiantar adalah salah satu sekolah swasta yang bergerak di bidang pendidikan yang berada dibawah naungan Yayasan Perguruan Sultan Agung Pematangsiantar yang memiliki visi "Unggul Dalam Prestasi Berdasarkan Rasa Percaya Diri, Iman Dan Taqwa”. Dalam upaya mencapai visi tersebut maka diperlukan kinerja yang baik dari guru maupun staf pegawai yang terlibat dalam pengelolaan aktivitas belajar mengajar di SMP Swasta Sultan Agung Pematangsiantar.

Fenomena kinerja guru dan staf pegawai di SMP swasta Sultan Agung Pematangsiantar menunjukkan adanya kinerja yang masih belum optimal atau berada dalam kategori sedang. Ini ditunjukkan melalui indikator kinerja guru dan staf pegawai yakni seperti pada tabel berikut ini: 
Iabal 1

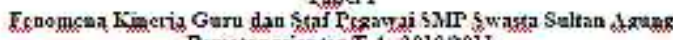

\begin{tabular}{|c|c|c|c|c|c|}
\hline $\begin{array}{c}\text { nimsesi } \\
\text { Kuxtilixs K.rjx }\end{array}$ & 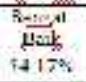 & $\frac{\mathrm{Fxin}}{2 \sin \%}$ & 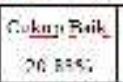 & 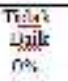 & 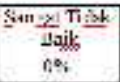 \\
\hline$\overline{\mathrm{K}}$ ux liLAx $\mathrm{K}, \cdot \mathrm{j} \times \mathrm{x}$ & $41 \mathrm{~A} 2 \mathrm{x}^{2}$ & 44448 & $13<084$ & $m_{1}$ & $n$. \\
\hline Frtecstan Walru & $+1: 78$ & $2124^{\circ} \mathrm{i}$ & 26 398: & $m$ & 09 \\
\hline Kebadiras & $21,63 \%$ & $\therefore 2,20 \%$ & $11,21: 8$ & W's & Uts \\
\hline 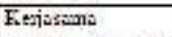 & $37 \mathrm{ins}$ & $72,78^{6}$ & $272 \%$ & $m$ & $n$ \\
\hline
\end{tabular}

baik perlu ditingkatkan menjadi baik, dan yang sudah berkategori baik harus dapat dipertahankan. Kinerja dipengaruhi oleh berbagai faktor, antara lain kepemimpinan, motivasi, budaya organisasi, kompensasi, dan salah satunya adalah komunikasi.

Dalam proses komunikasi, melibatkan beberapa faktor yakni komunikator, pesan, media, dan komunikan. Kepala sekolah selaku komunikator menyampaikan pesan kepada komunikan (guru dan staf pegawai) melalui berbagai media baik secara lisan maupun tertulis. Komunikasi yang terjadi kepada guru misalnya memberikan jadwal tugas mengajar kepada setiap guru, petunjuk teknis dalam pembuatan soal ujian dan nilai ujian, penentuan jadwal mengawas pada saat ujian. Sedangkan komunikasi kepada staf pegawai misalnya mengumpulkan data siswa dan mengisinya ke dalam buku induk, mengumpulkan berkas dan arsip guru guna kelengkapan administrasi, pengetikan dan pencetakan soal ujian.

Dalam melaksanakan perintah tersebut, adakalanya tidak sesuai dengan apa yang diperintahkan (misalnya keterlambatan penyerahan soal ujian, penyerahan nilai tidak tepat pada waktu yang telah ditentukan, dan lain sebagainya). Hal ini tentu menjadi suatu masalah karena pelaksanaan tugas akan menjadi terkendala.

\section{Rumusan Masalah}

Berdasarkan uraian pada latar belakang di atas, permasalahan yang akan diangkat dalam penelitian ini adalah:

a. Bagaimana gambaran komunikasi kepala sekolah dan kinerja guru dan staf pegawai pada SMP Swasta Sultan Agung Pematangsiantar?

b. Seberapa besar pengaruh komunikasi kepala sekolah terhadap kinerja guru dan staf pegawai pada SMP Swasta Sultan Agung Pematangsiantar?

\section{Tujuan Penelitian}

Adapun tujuan penelitian ini adalah:

a. Untuk mengetahui gambaran komunikasi kepala sekolah dan kinerja guru dan staf pegawai pada SMP Swasta Sultan Agung Pematangsiantar.

b. Untuk mengetahui besarnya pengaruh komunikasi kepala sekolah terhadap kinerja guru dan staf pegawai pada SMP Swasta Sultan Agung Pematangsiantar.

\section{Metode Penelitian}

Desain penelitian merupakan suatu cara yang sistematis dan objektif dengan maksud untuk memperoleh data atau mengumpulkan keterangan untuk diteliti. Adapun Desain penelitian yang digunakan dalam penulisan skripsi ini adalah Penelitian Kepustakaan (Library Research) dan Penelitian Lapangan (Field Research). Sumber data yang digunakan dalam penelitian ini adalah data primer dan data sekunder.

Teknik pengumpulan data yang dilakukan penulis dalam penelitian ini adalah berupa Kuesioner, Wawancara dan Dokumentasi. Tehnik analisa data yang digunakan dalam penelitian ini antara lain Tehnik Analisa Deskriptif Kualitatif dan Tehnik Analisa Deskriptif Kuantitatif.

\section{B. LANDASAN TEORI}

Menurut Daft (2002:8) manajemen adalah pencapaian sasaran-sasaran organisasi dengan cara yang efektif dan efisien melalui perencanaan, pengorganisasian, kepemimpinan, dan pengendalian sumber daya organisasi.

Menurut Rivai (2004:9) manajemen sumber daya manusia adalah salah satu bidang dari manajemen umum yang meliputi segi-segi perencanaan, pengorganisasian, pelaksanaan, dan pengendalian.

Menurut Rivai (2004:16) fungsi operasional manajemen sumber daya manusia meliputi :

1. Pengadaan Tenaga Kerja (SDM)

Pengadaan adalah proses penarikan, seleksi, penempatan untuk mendapatkan karyawan yang sesuai dengan yang dibutuhkan oleh organisasi.

2. Pengembangan

Pengembangan adalah proses peningkatan keterampilan teknis, teoritis, konseptual dengan moral karyawan melalui pendidikan dan pelatihan yang diberikan dan harus sesuai dengan kebutuhan pekerjaan masa kini dan di masa yang akan datang.

3. Kompensasi

Kompensasi adalah pemberian balas jasa langsung maupun tidak langsung uang ataupun barang kepada karyawan sebagai balas jasa yang diberikan kepada organisasi. Prinsip kompensasi adalah adil dan layak. Adil diartikan sesuai dengan prestasi kerjanya, sedangkan layak diartikan dapat memenuhi kebutuhan primernya serta berpedoman pada upah minimum pemerintah.

4. Pengintegrasian

Pengintegrasian adalah kegiatan untuk mempersatukan kepentingan organisasi dengan kebutuhan karyawan agar tercipta kerja sama yang serasi dan saling menguntungkan

5. Pemeliharaan

Pemeliharaan adalah kegiatan untuk memelihara kondisi mental, fisik dan loyalitas karyawan kepada organisasi agar mereka mau tetap bekerja sama sampai masa kerja berakhir.

6. Pemberhentian (Pemutusan Hubungan Kerja)

Pemberhentian (Pemutusan Hubungan Kerja) adalah putusnya hubungan kerja seseorang dari suatu organisasi dikarenakan kontrak kerja berakhir, pensiun dan sebab-sebab lainnya.

Istilah komunikasi berasal dari bahasa latin, communicatio yang berarti pemberitahuan, pemberian bagian, pertukaran dimana pembicara mengharapkan pertimbangan atau jawaban dari 
pendengarnya. Komunikasi merupakan proses pemindahan pesan yang melibatkan dua orang atau lebih dan dapat dilakukan dengan menggunakan cara-cara berkomunikasi yang biasa dilakukan oleh seseorang melalui lisan, tulisan maupun sinyalsinyal nonverbal.

Menurut Arifin (2008:11), komunikasi adalah ilmu kemasyarakatan yang mempelajari secara sistematis segala segi pernyataan antar manusia. Vardiansyah (2011:4) mengatakan bahwa pengirim pesan atau komunikator yang dimaksud di sini adalah manusia yang mengambil inisiatif dalam berkomunikasi.

Komunikasi biasa terjadi dalam berbagai bentuk, misalnya percakapan melalui telepon, mendengarkan radio, tatap muka langsung, memo, dan lain sebagainya. Menurut Purwanto (2006:5), pada dasarnya terdapat dua bentuk dasar komunikasi yang lazim digunakan, yaitu komunikasi verbal dan komunikasi non verbal.

Meskipun semua organisasi harus melakukan komunikasi dengan berbagai pihak dalam mencapai tujuannya, namun perlu diketahui bahwa pendekatan yang dipakai antara satu organisasi dengan organisasi yang lain dapat bervariasi atau berbeda. Bagi perusahaan yang berskala kecil yang hanya memiliki karyawan, maka penyampaian informasi dapat dilakukan secara langsung kepada para karyawannya. Namun, pada perusahaan besar yang memiliki ratusan bahkan ribuan karyawan, maka penyampaian informasi kepada mereka merupakan suatu pekerjaan yang cukup rumit.

Menurut Bovee dan Thill dalam Purwanto (2006:13), faktor-faktor penghambat komunikasi tersebut dikelompokkan ke dalam empat masalah utama yang mencakup masalah dalam pengembangan pesan, penyampaian pesan, penerimaan pesan, dan penafsiran pesan.

Kinerja adalah sebuah kata dalam bahasa Indonesia dari kata dasar "kerja" yang menterjemahkan kata dari bahasa asing prestasi. Menurut Rivai dalam Handoko (2004 :104), kinerja merupakan perilaku yang nyata yang ditampilkan setiap orang sebagai prestasi kerja yang dihasilkan oleh karyawan sesuai dengan perannya dalam perusahaan.

Menurut Mathis (2002:378), kinerja pada dasarnya adalah apa yang dilakukan atau tidak dilakukan oleh karyawan. Kinerja karyawan yang umum untuk kebanyakan pekerjaan meliputi elemen sebagai berikut :

1. Kuantitas dari hasil : volume kerja yang dihasilkan di bawah kondisi normal.

2. Kualitas dari hasil : kerapian, ketelitian dan keterkaitan hasil dengan tidak mengabaikan volume pekerjaan.

3. Ketetapan waktu dari hasil : penggunaan masa kerja yang disesuaikan dengan kebijaksanaan perusahaan

4. Kehadiran : kehadiran setiap harinya di tempat kerja.
5. Kemampuan bekerja sama : kemampuan menangani hubungan dalam melakukan pekerjaan.

Penilaian kinerja (performance appraisal) pada dasarnya merupakan faktor kunci guna mengembangkan suatu organisasi secara efektif dan efisien, karena adanya kebijakan atau program yang lebih baik atas sumber daya manusia yang ada dalam organisasi. Penilaian kinerja individu sangat bermanfaat bagi dinamika pertumbuhan organisasi secara keseluruhan, melalui penilaian tersebut maka dapat diketahui kondisi sebenarnya tentang bagaimana kinerja karyawan.

Menurut Furtwengler (2002:1) penilaian kinerja menyediakan dasar bagi organisasi untuk menilai :

1) Bagaimana kemajuan atas sasaran yang telah ditetapkan.

2) Membantu dalam mengenali area-area kekuatan dan kelemahan.

3) Menentukan tindakanyang tepat untuk meningkatkan kinerja.

4) Menunjukkan bagaimana kegiatan mendukung tujuan organisasi.

5) Membantu dalam membuat keputusan-keputusan dengan langkah inisiatif.

6) Mengutamakan alokasi sumber daya.

7) Meningkatkan produk-produk dan jasa-jasa kepada pelanggan.

Menurut Kiswanto (2010:2) Komunikasi dapat dilakukan dengan berbagai cara, dengan mengandalkan media telepon, internet, via sms dan sebagainya maka kebutuhan komunikasi antara sesama karyawan bahkan dengan pimpinan dapat berjalan dengan baik. Hal inilah yang terus dilakukan untuk meningkatkan kinerja mereka baik secara kualitas maupun kuantitasnya.

Penulis menyimpulkan bahwa pimpinan harus mempunyai komunikasi yang efektif dalam menyampaikan pesan kepada bawahannya agar pesan yang disampaikan tersebut dapat dilaksanakan secara tepat dan sesuai dengan keinginan atasan. Di samping itu, bawahan juga harus memiliki kemampuan komunikasi yang baik dalam menerima setiap pesan yang disampaikan oleh atasan sehingga mereka dapat melakukan aktivitas sesuai dengan yang diperintahkan secara baik.

\section{PEMBAHASAN}

\section{Analisa Deskriptif Kualitatif}

Analisa deskriptif bertujuan untuk mendapatkan gambaran atau deskripsi mengenai tanggapan guru mengenai pengaruh komunikasi terhadap kinerja guru di SMP Swasta Perguruan Sultan Agung Pematangsiantar. Sesudah pengujian anda, maka langkah selanjutnya peneliti melakukan pengkajian analisis kualitatif sebagai gambaran fenomenal dari variabel penelitian pada saat sekarang ini. 


\section{a. Pelaksanaan Komunikasi Pada SMP Swasta Perguruan Sultan Agung Pematangsiantar}

Salah satu faktor yang dapat menpengaruhi kinerja guru dan pegawai dalam melaksanakan pekerjaannya adalah komunikasi. Suatu komunikasi dikatakan efektif apabila terjadi pemahaman yang sama dan merangsang pihak lain untuk merespon. Pada SMP Swasta Sultan Agung Pematangsiantar, salah satu faktor penting seorang Kepala Sekolah dalam membangkitkan, mengarahkan, dan memelihara perilaku yang berhubungan dengan meningkatkan kinerja adalah dengan komunikasi. Adapun ruang lingkup komunikasi yang terjadi pada SMP Swasta Sultan Agung Pematangsiantar yaitu komunikasi secara internal dan eksternal.

Komunikasi internal mencakup hubungan komunikasi antara Kepala Sekolah dan guru beserta pegawai. Kepala Sekolah memberikan informasi mengenai visi dan misi, standar kurikulum kepada guru dan kelengkapan administrasi kepada pegawai yang diharapkan mampu membangkitkan kinerja dengan menciptakan feedback antara Kepala Sekolah dan guru serta pegawai. Sehingga komunikasi mampu berjalan dengan efektif baik melalui lisan maupn tulisan berupa silabus, laporan bulanan dan tahunan, rekapitulasi kehadiran. Selain komunikasi tentang pekerjaan, kepala sekolah juga menjalin rasa kekeluargaan dengan menciptakan suatu perasaan sebagai komunitas antar guru dan pegawai.

SMP Swasta Sultan Agung Pematangsiantar juga menjalin hubungan komunikasi secara eksternal yaitu dengan murid dan orang tua murid demi menjamin peningkatan nilai hasil belajar siswa. Kepala Sekolah SMP Swasta Sultan Agung Pematangsiantar memberikan arahan, bimbingan serta pengenalan visi dan misi sekolah. Guru-guru menjalin hubungan baik dengan siswa dengan cara memberikan materi sesuai dengan kebutuhan dan kurikulum yang berlaku dan tidak bertentangan dengan undang-undang. Bersosialisasi dengan orang tua siswa tentang hasil belajar dan prilaku seharihari siswa saat berada di dalam maupun di luar lingkungan sekolah.

Dari hasil survey, dapat dilihat bahwa jawaban responden atas pertanyaan kepala sekolah menyampaikan pesan dengan ramah kepada guru dan staf pegawai diperoleh nilai rata-rata 4,00 dan dikategorikan baik. Pada pertanyaan kepala sekolah dapat bersosialisasi dengan guru dan staf pegawai diperoleh nilai rata-rata 4,03 dan dikategorikan baik. Hal ini dikarenakan komunikator dapat menyampaikan pesan / informasi dengan baik kepada setiap guru dan staf pegawai.

Untuk pertanyaan penyampaian pesan dengan jelas kepada guru dan staf pegawai diperoleh nilai rata-rata 3,86 dan dikategorikan baik. Sedangkan untuk pertanyaan penyampaian informasi yang sesuai dengan pekerjaan kepada guru dan staf pegawai diperoleh nilai rata-rata 4,61 dan dikategorikan sangat baik. Hal ini dikarenakan aliran pesan yang terjadi dari kepala sekolah kepada guru dan staf pegawai dan sebaliknya adalah cukup baik
Indikator media penyampaian pesan secara lisan dari kepala sekolah kepada guru dan staf pegawai diperoleh nilai rata-rata 4,58 dan dikategorikan sangat baik. Dan media penyampaian pesan secara tertulis dari kepala sekolah kepada guru dan staf pegawai diperoleh nilai rata-rata 4,31 dan dikategorikan sangat baik. Hal ini disebabkan karena guru dan staf pagawai dapat menerima dan mengerti isi informasi / pesan yang diberikan oleh kepala sekolah baik secara lisan maupun tertulis.

Indikator komunikan yang terdiri dari pertanyaan kepala sekolah mendengarkan hal yang disampaikan guru dan staf pegawai diperoleh nilai rata-rata 4,25 dan dikategorikan sangat baik. Kepala sekolah mendiskusikan masalah yang terjadi dengan guru dan staf pegawai diperoleh nilai rata-rata 4,08 dan dikategorikan baik. Hal ini disebabkan terdapat perbedaan kemampuan guru dan staf pegawai dalam menerima instruksi dan pesan yang disampaikan oleh kepala sekolah.

\section{b. Kinerja Guru dan Staf Pegawai pada SMP Swasta Sultan Agung Pematangsiantar.}

Kinerja guru dan staf pegawai merupakan suatu kemajuan atau pencapaian hasil kerja dengan kriteria tertentu yang dilakukan berdasarkan potensi yang dimilikinya. Faktor-faktor yang mempengaruhi kinerja guru dan staf pegawai pada SMP Swasta Sultan Agung Pematangsiantar adalah kemampuan individu yang dimiliki masing-masing guru dan pegawai dalam melaksanakan pekerjaannya secara tanggung jawab dan mandiri, pemanfaatan waktu bekerja secara maksimal. Disamping itu, faktor lingkungan yang turut menunjang kinerja guru dan pegawai SMP Swasta Sultan Agung Pematangsiantar seperti hubungan kerja yang harmonis, iklim kerja yang respek dan dinamis serta sarana dan prasarana yang memadai.

Kepala sekolah selaku pimpinan akan melakukan evaluasi atas kinerja guru selama tahun ajaran tertentu melalui rapat pleno kenaikan kelas untuk menilai hasil kerja guru yang ditunjukkan melalui prestasi belajar siswa. Sedangkan untuk kinerja staf pegawai, kepala sekolah melakukan evaluasi melalui kelengkapan administrasi dalam proses belajar mengajar yang harus disiapkan dengan baik dan tepat waktu. Penilaian kinerja ini ditujukan untuk memperbaiki hasil kerja dari guru dan staf pegawai untuk tahun ajaran berikutnya, dan pengaturan ulang untuk wali kelas setiap tahunnya.

Dari hasil survey, dapat dilihat bahwa untuk pertanyaan guru dan staf pegawai melakukan aktivitas seperti dalam uraian pekerjaan diperoleh nilai rata-rata 4,86 dan dikategorikan sangat baik. Sedangkan untuk pertanyaan guru dan staf pegawai mencapai hasil sesuai dengan yang diharapkan diperoleh nilai rata-rata 3,81 dan dikategorikan baik. Hal ini disebabkan kemampuan dan ketrampilan yang dimiliki guru dan staf pegawai dalam melaksanakan pekerjaan mereka.

Selanjutnya pertanyaan guru dan staf pegawai menyelesaikan tugas secara baik diperoleh nilai ratarata 4,25 dan dikategorikan sangat baik. Pertanyaan 
guru dan staf pegawai menggunakan kemampuan profesional dalam menyelesaikan pekerjaan diperoleh nilai rata-rata 4,31 dan dikategorikan sangat baik. Hal ini dikarenakan kepribadian yang dimiliki oleh masing-masing guru dan staf pegawai dalam melaksanakan tugas mereka.

Pertanyaan guru dan staf pegawai melaksanakan tugas setelah diberikan diperoleh nilai rata-rata 4,33 dan dikategorikan sangat baik. Untuk pertanyaan guru dan staf pegawai menyelesaikan pekerjaan sesuai dengan waktu yang ditargetkan diperoleh nilai rata-rata 3,97 dan dikategorikan baik. Hal ini disebabkan perbedaan karakter dari masingmasing guru dan staf pegawai dalam mengatur waktu kerjanya.

Sedangkan indikator kehadiran di tempat kerja, pertanyaan guru dan staf pegawai diperoleh nilai rata-rata 4,11 dan dikategorikan baik. Dan pertanyaan guru dan satf pegawai hadir sesuai dengan jadwal yang ditentukan diperoleh nilai ratarata 4,33 dan dikategorikan sangat baik. Hal ini disebabkan perbedaan lokasi tempat tinggal serta jadwal mengajar yang ditentukan kepadanya sehingga kehadiran ditempat kerja untuk setiap guru dan staf pegawai adalah berbeda.

Untuk pertanyaan guru dan staf pegawai saling bekerja sama dalam menyelesaikan pekerjaan diperoleh nilai rata-rata 4,39 dan dikategorikan sangat baik. Pertanyaan guru dan staf pegawai saling memberikan informasi yang mendukung pekerjaan mereka diperoleh nilai rata-rata 4,17 dan dikategorikan baik. Hal ini disebabkan perbedaan suku, ras dan agama yang berpengaruh terhadap tingkat kerjasama diantara mereka.

\section{Analisa Deskriptif Kuantitatif}

\section{a. Analisis Regresi}

Berdasarkan data hasil penginputan daftar kuesioner yang diperoleh maka dapat dicari pengaruh antara komunikasi (variabel $\mathrm{X}$ ) dengan kinerja guru dan pegawai (variabel Y) melalui rumus regresi seperti berikut :

$$
\hat{\mathrm{Y}}=a+b \cdot x
$$

Dalam menentukan koefisien " a " dan " $b$ ", digunakan rumus berikut :

$$
\begin{aligned}
& b=\frac{n \cdot \sum X Y-\sum X \cdot \sum Y}{n \cdot \sum X^{2}-\left(\sum X\right)^{2}} \\
& b=\frac{36 * 51793-1214 * 1531}{36 * 41194-(1214)^{2}} \\
& \mathrm{~b}=0,644 \quad \text { dan } \\
& a=\bar{Y}-b \cdot \bar{X} \\
& a=\frac{1531}{36}-0,644 * \frac{1214}{36} \\
& \mathrm{a}=20,822
\end{aligned}
$$

Dari perhitungan di atas diperoleh koefisien regresinya adalah seperti berikut:

$$
\hat{\mathrm{Y}}=20,822+0,644 . \mathrm{X}
$$

Artinya terdapat pengaruh positif antara variabel bebas (komunikasi) dengan variabel terikat (kinerja) pada SMP Swasta Sultan Agung Pematangsiantar, dimana semakin baik komunikasi kepala sekolah yang dilakukan maka semakin baik juga kinerja guru dan staf pegawai.

\section{b. Analisa Koefisien Korelasi dan Determinasi}

Berdasarkan data hasil penginputan daftar kuesioner yang diperoleh maka dapat dicari hubungan antara komunikasi (variabel X) dengan kinerja guru dan pegawai (variabel Y) melalui rumus korelasi seperti berikut :

$$
\begin{aligned}
r & =\frac{n \cdot \Sigma X Y-\Sigma X \cdot \Sigma Y}{\sqrt{n \Sigma X^{2}-(\Sigma X)^{2}} \cdot \sqrt{n \Sigma Y^{2}-(\Sigma Y)^{2}}} \\
r & =\frac{36 * 51793-1214 * 1531}{\sqrt{36 * 41194-(1214)^{2}} \cdot \sqrt{36 * 65433-(1531)^{2}}} \\
r & =\frac{5914}{\sqrt{9188} \cdot \sqrt{11627}} \\
\mathrm{r} & =0,5722
\end{aligned}
$$

Dari hasil perhitungan diatas, terdapat hubungan yang sedang dan positif antara variabel $\mathrm{X}$ (komunikasi) terhadap variabel Y (kinerja). Untuk mengukur seberapa besar variabel bebas menjelaskan variabel terikat maka digunakan koefisien determinasi yaitu :

$$
\begin{aligned}
& \mathrm{KD}=\mathrm{r}^{2} \times 100 \% \\
& \mathrm{KD}=(0,5722)^{2} \times 100 \% \\
& \mathrm{KD}=32,74 \%
\end{aligned}
$$

Dari hasil perhitungan diatas, diketahui bahwa variabel komunikasi kepala sekolah dapat menjelaskan naik turunnya kinerja guru dan staf pegawai di SMP Swasta Sultan Agung Pematangsiantar sebesar $32,74 \%$ dan sisanya 67,26 $\%$ dapat dijelaskan oleh faktor lain yang tidak dibahas dalam penelitian ini, seperti motivasi, budaya organisasi, kompensasi, dan faktor lainnya.

\section{c. Uji Hipotesis}

Selanjutnya untuk menguji pengaruh variabel bebas terhadap variabel terikat, digunakan uji $t$ dengan rumus sebagai berikut :

$$
\begin{aligned}
& t=\frac{0,5722 \sqrt{36-2}}{\sqrt{1-(0,5722)^{2}}} \\
& \mathrm{t}=4,068
\end{aligned}
$$

Karena $\mathrm{t}_{\text {hitung }}$ lebih besar dari $\mathrm{t}_{\text {tabel }}(4,068>$ 2,033), maka $\mathrm{H}_{0}=0$ ditolak, artinya bahwa komunikasi kepala sekolah berpengaruh positif terhadap kinerja guru dan pegawai pada SMP Swasta Sultan Agung Pematangsiantar.

\section{Evaluasi}

a. Komunikasi Kepala Sekolah pada SMP Swasta Sultan Agung Pematangsiantar

Komunikasi yang terjadi pada SMP Swasta Sultan Agung Pematangsiantar dilakukan secara lisan dan tertulis baik melalui media elektronik melalui fasilitas telepon kantor, fax, handphone, dan fasilitas internet, maupun media konvensional melalui fasilitas surat-menyurat berupa surat keterangan, surat keputusan, surat teguran, surat peringatan, surat permohonan, dan surat undangan.

Komunikasi pada SMP Swasta Sultan Agung Pematangsiantar dinilai berdasarkan indikator 
komunikator, pesan, media, dan komunikan. Komunikator (dalam hal ini kepala sekolah), mayoritas guru dan staf pegawai memberikan jawaban baik atas keramahan dan tingkat sosialisasi yang ditunjukkan oleh kepala sekolah kepada mereka, akan tetapi ada beberapa guru dan staf pegawai yang memberikan jawaban cukup baik dikarenakan sikap dan perkataan yang tegas kepada mereka. Dalam indikator pesan, guru dan staf pegawai mayoritas memberikan jawaban sangat baik dikarenakan kepala sekolah secara jelas dan tepat dalam menyampaikan informasi kepada mereka, akan tetapi ada beberapa guru dan staf pegawai yang memberkan jawaban cukup baik dikarenakan informasi yang disampaikan sekaligus dalam jumlah sangat banyak sehingga ada informasi yang terlupakan.

Selanjutnya dalam indikator media, rata-rata guru dan staf pegawai memberikan jawaban sangat baik atas penyampaian informasi dari kepala sekolah baik secara lisan maupun tertulis, akan tetapi ada beberapa guru dan staf pegawai yang memberikan jawaban cukup baik dikarenakan kebanyakan informasi yang disampaikan adalah secara lisan sehingga tidak sepenuhnya informasi yang diserap oleh mereka. Dalam indikator komunikan, mayoritas guru dan staf pegawai memberikan jawaban baik atas perhatian kepala sekolah dalam menerima informasi yang mereka berikan, akan tetapi ada beberapa guru dan staf pegawai yang memberikan jawaban cukup baik dikarenakan realisasi atas masukan yang mereka berikan jarang terlaksana dengan baik.

\section{b. Kinerja Guru dan Staf Pegawai pada SMP Swasta Sultan Agung Pematangsiantar}

Kinerja guru dan staf pegawai pada SMP

Swasta Sultan Agung Pematangsiantar dapat dilihat dari indikator kuantitas hasil, kualitas hasil, ketepatan waktu, kehadiran, dan kemampuan bekerja sama. Dalam indikator kuantitas hasil berada dalam kategori baik karena rata-rata guru dan staf pegawai dapat melakukan aktivitas sesuai dengan penjelasan dalam uraian pekerjaan, akan tetapi, hasil yang dicapai belum optimal dikarenakan masih banyak guru dan staf pegawai yang belum dapat menyelesaikan pekerjaan sesuai dengan yang diharapkan.

Dalam indikator kualitas hasil berada dalam kategori baik dikarenakan guru dan staf pegawai dapat melaksanakan tugas dengan baik dan professional, akan tetapi, masih ada beberapa guru dan staf pegawai yang masih belum berpengalaman dengan tingkat pendidikan yang belum memadai. Indikator ketepatan waktu berada dalam kategori baik dikarenakan rata-rata guru dan staf pegawai dapat menyelesaikan pekerjaan sesuai dengan waktu yang ditargetkan, akan tetapi, ada beberapa orang guru dan staf pegawai yang masih menunda pekerjaan sehingga menyebabkan pekerjaan tidak dapat diselesaikan dengan tepat waktu.

Selanjutnya dari indikator kehadiran berada dalam kategori baik, mayoritas guru dan staf pegawai dapat hadir sesuai dengan waktu dan jadwal yang telah ditentukan, akan tetapi, masih ada beberapa orang guru dan staf pegawai yang tidak dapat hadir tepat waktu dikarenakan lokasi tempat tinggal yang jauh dari sekolah dan faktor kemacetan yang terjadi. Sedangkan dari indikator kemampuan bekerjasama berada dalam kategori baik dikarenakan guru dan staf pegawai dapat saling bertukar informasi, saling mendukung dan bekerjasama dalam melaksanakan pekerjaan mereka, akan tetapi, ada beberapa guru dan staf pegawai yang tidak mampu untuk bekerjasama dengan yang lain dikarenakan kepribadian serta keengganan mereka untuk berbaur dengan yang lainnya.

\section{KESIMPULAN DAN SARAN}

\section{Kesimpulan}

Adapun kesimpulan-kesimpulan yang dapat diberikan oleh Penulis dari penelitian yang telah dilakukan adalah sebagai berikut:

a. Hasil dari jawaban responden mengenai komunikasi kepala sekolah berada pada nilai rata-rata tertinggi yaitu 4,61 dengan kategori sangat baik dan nilai rata-rata terendah berada pada 3,86 dengan kategori baik. Sedangkam hasil jawaban responden mengenai kinerja guru dan staf pegawai berada pada nilai rata-rata tertinggi yaitu 4,86 dengan kategori sangat baik dan nilai rata-rata terendah 3,81 dengan kategori baik.

b. Komunikasi kepala sekolah berpengaruh terhadap kinerja guru dan staf pegawai, hal ini dapat dilihat dari koefisien regresi yang bertanda positif yaitu: $\hat{\mathrm{Y}}=20,822+0,644 \mathrm{X}$, artinya semakin baik komunikasi kepala sekolah yang diterapkan maka kinerja guru dan staf pegawai akan semakin tinggi. Dengan nilai $r=0,5722$ terdapat hubungan yang sedang antara komunikasi kepala sekolah dengan kinerja guru dan staf pegawai. kinerja guru dan staf pegawai melalui koefisien dterminasi (KD) sebesar 32,74 $\%$ dapat dijelaskan oleh komunikasi kepala sekolah dan sisanya sebesar 67,26 \% dapat dijelaskan faktor lain yang tidak dibahas dalam penelitian ini.

c. Dari hasil pengujian $t_{\text {hit }}=4,068$ sedangkan $t_{\text {tab }}$ pada tingkat kepercayaan adalah sebesar 2,033. Oleh karena itu $t_{\text {hit }}>t_{\text {tab }}$, sehingga Ho ditolak dan Ha diterima, berarti variabel komunikasi kepala sekolah berpengaruh terhadap kinerja guru dan staf pegawai pada SMP Swasta Sultan Agung Pematangsiantar.

\section{Saran}

Adapun saran-saran yang Penulis berikan sebagai upaya untuk memecahkan masalah yang dihadapi adalah sebagai berikut:

a. Komunikasi yang diterapkan pada SMP Swasta Sultan Agung Pematangsiantar sudah efektif, meskipun pada hasil rekapitulasi jawaban kuesioner mengenai komunikasi pada pertanyaan kepala sekolah menyampaikan pesan dengan jelas mempunyai nilai terendah yaitu 3,86 tetapi 
masih dalam kategori baik. Hal ini harus menjadi perhatian bagi kepala sekolah dengan melaksanakan perbaikan komunikasi sehingga akan meningkatkan efektifitas komunikasi yang terlaksana di SMP Swasta Sultan Agung Pematangsiantar.

b. Kinerja guru dan staf pegawai pada SMP Swasta Sultan Agung Pematangsiantar sudah optimal, meskipun pada hasil rekapitulasi jawaban kuesioner mengenai kinerja guru dan staf pegawai pada pertanyaan guru dan staf pegawai mencapai hasil sesuai dengan yang diharapkan memiliki nilai terendah yaitu 3,81 tetapi masih dalam kategori baik. Dalam hal ini, untuk meningkatkan kinerja guru dan staf pegawai, kepala sekolah perlu memberikan petunjuk teknis pekerjaan kepada guru dan staf pegawai sehingga dapat melaksanakan tugasnya sesuai ketentuan dan memperoleh hasil yang sesuai dengan harapan.

c. Menyediakan sarana dan prasarana yang menunjang aktivitas belajar mengajar dan berusaha menciptakan hubungan yang baik antara kepala sekolah dengan guru dan staf pegawai sehingga menciptakan suasana kerja yang kondusif.

\section{E. DAFTAR PUSTAKA}

Arifin, H. Anwar, 2008, Ilmu Komunikasi, Jakarta : PT. Raja Grafindo Persada.

Daft, Richard L., Manajemen, Penerbit Salemba Empat, Jakarta, 2002.

Furtwengler, Dale, 2002, Penuntun Sepulh Menit Penilaian Kinerja, Yogyakarta : Penerbit ANDI.

Handoko, T. Hani, 2004, Manajemen Personalia dan Sumber Daya Manusia, Yogyakarta : BPFE.

Kiswanto, M., 2010, Jurnal : Pengaruh Kepemimpinan Dan Komunikasi Terhadap Kinerja Karyawan KALTIM Pos Samarinda, diakses tahun 2012.

Mathis, Robert, 2002, Perilaku Organisasi, Jakarta : Bumi Aksara.

Purwanto, Djoko, 2006, Komunikasi Bisnis, Jakarta : Erlangga.

Rivai, Veithzal, 2004, Performance Appraisal, Jakarta : PT. Raja Grafindo Persada.

Vardiansyah, 2011, http://repository.usu.ac.id/bitstream/123456 789/21092/4/ Chapter\%20II.pdf : 4., diakses tahun 2012. 